\title{
Trepidation greets plan for cloning humans
}

\section{Alison Abbott}

Fireworks erupted in Rome last week at an international workshop on human and therapeutic cloning as the meeting's organizers clashed with their critics and the press.

Held at La Sapienza, Rome's largest university, the workshop attracted as many journalists as scientists, and was attended by few of the established experts in cloning technology. Instead, it drew criticism from Italian researchers who feared that it was likely to damage the reputation of Italian biomedical research.

The workshop was organized by Romebased obstetrician Severino Antinori, Panayiotis Zavos, a fertility researcher from Kentucky, and their new partner, Avi BenAbraham, an Israeli physician. The three announced that they would set a date for their first human cloning attempt at a meeting planned for Monaco in October. The experiment is set to take place in an unnamed southern Mediterranean country, they said.

But no details were forthcoming in Rome of the technologies that the trio plans to use to ensure an acceptably high rate of healthy births. Zavos spoke only of reducing errors by using good "quality control" of embryo selection.

Ian Wilmut of the Roslin Institute near Edinburgh, head of the Scottish research team that cloned Dolly the sheep, did not attend the meeting but said afterwards that he doubts that such a reduction is currently feasible. Wilmut noted that low success rates are apparent in each of the five species that have already been cloned, including rhesus monkeys, in which only $4 \%$ of reconstructed embryos survive. "We are good at selection," he said, "but our survival rates [in farm animals] are still very low and most pregnancy failures occur just before term, which would be devastating and cruel for humans."

At one point during the meeting, according to several observers, Antinori had to be physically restrained from trying to prevent a young doctor from speaking out against the workshop. The doctor said that a conference on human cloning, which has been barred as unethical by several international organizations and governments, should not have been allowed in a public building, still less in a renowned university such as La Sapienza.

At another point Antinori warned journalists that he was successful in suing those whose reporting he considered defamatory or incorrect. In the week running up to the conference, Antinori brought actions against at least two newspaper writers, including Carlo Redi, a professor at the University of Pavia, and a member of the Italian government advisory committee on stem cells, who writes newspaper columns.
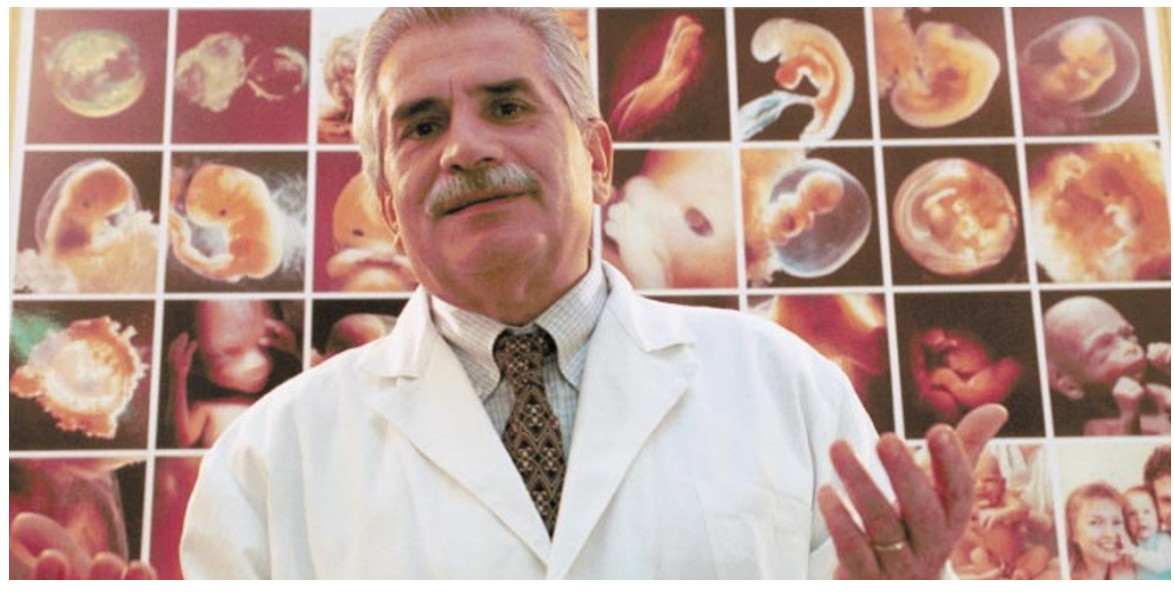

Controversial concept: meeting organizer Severino Antinori is preparing to clone a human being.

Redibelieves that the workshop threatens the standing of Italian biomedical science, which, he points out, is already suffering from the so-called Di Bella affair, in which an octogenarian doctor notoriously proclaimed a cure for cancer (see Nature 391, 217; 1998).

Redi claims that the announcement of the workshop in February prompted Umberto Veronesi, the health minister, to ban all cloning work in both humans and animals.

And according to Wilmut, the plan to press ahead with human cloning could contribute to a backlash outside of Italy against important research, such as therapeutic cloning.

\section{Singapore invests in bioinformatics}

\section{David Cyranoski, Tokyo}

Plans for a new institute in Singapore could address one of the most acute skills shortages in science by producing up to 100 trained bioinformaticists a year.

The planned Bioinformatics Institute is part of Singapore's US\$1 billion-a-year effort to turn the island into a powerhouse of biomedical research. Within five years, the institute should be delivering 100 masters degrees in bioinformatics. This is more than any other institution in the world, says Limsoon Wong, director of the Kent Ridge Digital Bioinformatics Laboratories, and one of the planners behind the institute.

According to Wong, training at the institute will go well beyond the curating of data. "We will be training people how to make predictions from the data concerning interaction between proteins, and how to use these data to drive experiments," he says.

The research and teaching institute will be housed temporarily at first, before moving to the planned 'biopolis' science park near the National University of Singapore, when it opens in two years time. The government has yet to announce its funding level, but the park is expected to start with a grant of around $\$ \$ 100$ million (US\$60 million).

The institute is likely to absorb the

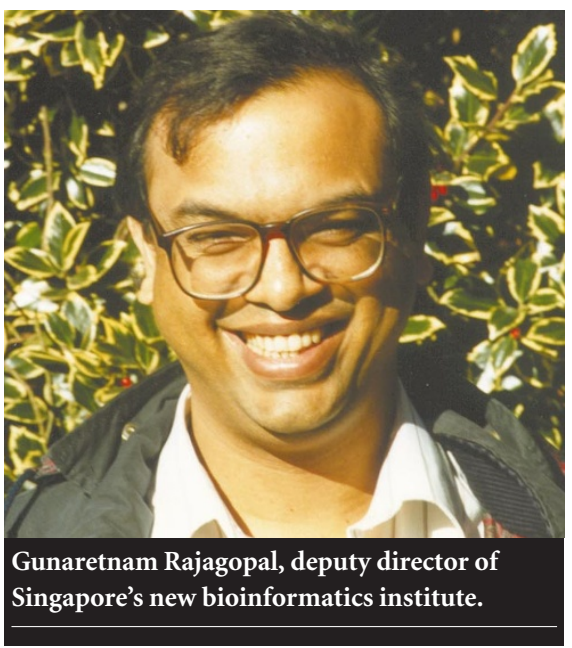

existing bioinformatics centre at the National University and to help service the nation's expanding genomics programme. Its own research programme will follow from the interests of the staff who will be recruited internationally.

Gunaretnam Rajagopal, a theoretical physicist at Cambridge University, has been named as the institute's deputy director, and starts work in July. "I find the opportunity to build a world-class research organization, with strong encouragement, commitment and active support of the government of Singapore, irresistible," he says. 